\title{
Ендоскопічна хірургія пухлин надниркових залоз при первинному гіперальдостеронізмі
}

\author{
А. О. Никоненко ${ }^{1}$, I. В. Русанов ${ }^{2}$, І. В. Зубрик ${ }^{1}$, О. О. Подлужний ${ }^{1}$, А. Л. Макаренков ${ }^{1}$ \\ 13апорізький державний медичний університет, \\ 23апорізька медична академія післядипломної освіти МОЗ України
}

\section{Endoscopic surgery of the suprarenal glands tumors in primary hyperaldosteronism}

\author{
A. O. Nykonenko ${ }^{1}$, I. V. Rusanov ${ }^{2}$, I. V. Zubryk ${ }^{1}$, O. O. Podluzhnyi ${ }^{1}$, A. L. Makarenkov ${ }^{1}$ \\ ${ }^{1}$ Zaporizhzhya State Medical University, \\ 2Zaporizhzhya Medical Academy of Postgraduate Education
}

\section{Реферат}

Мета. Оцінити ефективність хірургічного лікування пацієнтів з первинним гіперальдостеронізмом (ПГА).

Матеріали і методи. За період 32014 по лютий 2018 р. в клініці госпітальної хірургії Запорізького державного медичного університету у 46 пацієнтів діагностували ПГА, оперативне лікування проведено 23 пацієнтам, серед них 15 (65\%) жінок і 8 (35\%) чоловіків. Середній вік пацієнтів становив ( $52,3 \pm 9,5)$ року. За даними комп'ютерної (КТ) та магнітно-резонансної ( МРТ) томографії правобічна локалізація аденом надниркових залоз встановлена у 10 (43,5\%) пацієнтів, лівобічна - у 7 (30,4\%), двобічна у 6 (26,1\%). Розмір об'ємних утворень надниркових залоз становив $(18,3 \pm 6,7)$ мм. Діагностику проводили згідно з Клінічними практичними рекомендаціями з діагностики та лікування первинного гіперальдостеронізму (Clinical Practical Guideline - The Management of Primary Aldosteronism; 2008, 2016). Оперативне лікування проводили з використанням ендоскопічних методів. Лапароскопічну адреналектомію виконали 19 (82,6\%) пацієнтам, лапароскопічну резекцію надниркової залози - 4 (17,4\%). Результати оперативного лікування оцінювали згідно зі стандартними та клініко-біохімічними критеріями РASO (Рrimary Aldosteronism Surgical Outcomes).

Результати. Тривалість операцій становила в середньому 150 (120 - 200) хв, строки лікування пацієнтів у стаціонарі - (9 $\pm 2,1)$ доби. До конверсій не вдавалися, післяопераційних ускладнень не було. Ніхто з пацієнтів не помер. Порівняльний аналіз результатів оперативного лікування показав статистично достовірне зниження показників систолічного артеріального тиску (САТ), діастолічного артеріального тиску (ДАТ), концентрації альдостерону та підвищення рівня калію (р < 0,05). Кореляційний аналіз не виявив статистично достовірного зв'язку між концентрацією альдостерону та масою міокарда лівого шлуночка (ММлШ), товщиною міжшлуночкової перегородки (ТМШП), товщиною задньої стінки лівого шлуночка (ТЗСлш) у пацієнтів до та після оперативного лікування. Клінічні результати хірургічного лікування пацієнтів з ПГА, оцінені за критеріями РАSO та стандартними критеріями, практично схожі: повне одужання констатовано у 39,2 та 43,5\% пацієнтів, часткове - у 60,8 та 56,5\% пацієнтів відповідно біохімічні результати, оцінені аналогічно, суттєво різнилися: повне одужання - 91,3 та 43,5\%, часткове - 8,7 та 56,5\% відповідно. Висновки. В хірургічному лікуванні пацієнтів з аденомами надниркових залоз, що супроводжуються ПГА, слід надавати перевагу лапароскопічним методам (адреналектомія, резекція). Ефективність мініінвазивних методів хірургічного лікування ПГА статистично достовірна. Клініко-біохімічні критерії PASO в оцінці результатів хірургічного лікування пацієнтів з ПГА мають перевагу перед стандартними, оскільки є комплексними. Після хірургічного лікування пацієнтів з ПГА повне біохімічне одужання настає у 91,3\% пацієнтів, повне клінічне - у 39,2\%, часткове біохімічне - у 8,7\%, часткове клінічне - у 60,8\% пацієнтів.

Ключові слова: первинний гіперальдостеронізм; аденома надниркової залози; лапароскопічна адреналектомія; лапароскопічна резекція.

\section{Abstract}

Objective. To estimate the efficacy of surgical treatment of patients, suffering primary hyperaldosteronism (PHA).

Materials and methods. In a 2014 - Feb. 2018 yrs period in the Clinic of Hospital Surgery of the Zaporizhzhya State Medical University in 46 patients a PHA was diagnosed, operative treatment was conducted in 23 patients, among whom there were 15 ( $65 \%$ ) women and $8(35 \%)$ men. The average age have constituted $(52.3 \pm 9.5)$ yrs old. In accordance to the CT and MRT data a right-sided localization of the suprarenal glands adenomas was established in 10 (43.5\%) patients, a left-sided - in 7 (30.4\%), and a bilateral - in 6 (26.1\%). The dimensions of the volume suprarenal glands tumors have constituted $(18.3 \pm 6.7) \mathrm{mm}$. The diagnosis was conducted in accordance to the Clinical Practice Guideline for The Management of Primary Aldosteronism; 2008, 2016). Operative treatment was conducted, using endoscopic methods. Laparoscopic adrenalectomy was performed in $19(82.6 \%)$ patients, and laparoscopic resection of a suprarenal gland - in 4 (17.4\%). The results of operative treatment were estimated in accordance to standard and clinical-biochemical criteria PASO (Primary Aldosteronism Surgical Outcomes)

Results. The operation duration have constituted $150(120-200)$ min at average, and duration of the patients' stationary stay - (9 \pm 2.1$)$ days. There were no conversions, nor postoperative morbidity. Nobody of the patients died. Comparative analysis of the operative treatment results have shown a statistically trustworthy lowering of the systolic arterial pressure indices (CAT), diastolic arterial pressure (DAP), concentration of aldosterone and raising of the potassium level $(\mathrm{p}<0.05)$. Correlation analysis did not reveal a statistically trustworthy connection between concentration of aldosterone and the left ventricle myocardial mass, the interventricle septum thickness, thickness of the left ventricle posterior wall in the patients before and after the operative treatment. Clinical results of surgical treatment of patients, suffering PHA, estimated in accordance to PASO criteria and the standard criteria, are practically similar: complete recovery was registered in 39.2 and $43.5 \%$ patients, and a partial one - in 60.8 and 56.5\% patients, accordingly; biochemical results, estimated similarly, have been differed essentially: complete recovery -91.3 and $43.5 \%$, and a partial one -8.7 and $56.5 \%$ accordingly.

Conclusion. In surgical treatment of the patients with the suprarenal glands adenomas, accompanied by PHA, it is mandatory to give advantage to laparoscopic methods (adrenalectomy, resection). The efficacy of miniinvasive methods of surgical treatment of PHA is statistically trustworthy. Clinico-biochemical criteria PASO in estimation of the surgical treatment results in patients, suffering PHA, have advantage over the standard, because they are complex. After surgical treatment of the patients, suffering PHA, a complete biochemical recovery occurs in $91.3 \%$ patients, complete clinical one - in 39.2\%, partial biochemical - in $8.7 \%$, partial clinical - in $60.8 \%$.

Keywords: primary aldosteronism; adenoma of a suprarenal gland; laparoscopic adrenalectomy; laparoscopic resection. 
Хірургічний підхід у лікуванні патології надниркових залоз започатковано понад 120 років тому. Першу вдалу адреналектомію 36-річній пацієнтці з клінічно вираженим гірсутизмом та аменореєю виконав у 1889 р. лондонський хірург Knowsley Thornton [1, 2], першу ЛАЕ Michael Gagner y 1992 р. Ретроперитонеоскопічна методика виконання операції успішно була застосована в 1994 р. Першу лапароскопічну резекцію надниркової залози у пацієнта з альдостерон-продукуючою аденомою виконали Walz і співавтори в 1996 р. У 1999 р. L. Piazza і співавтори повідомили про першу робот-асистовану адреналектомію. Активно впроваджується в практику однопортова хірургія. Однак досі ЛАЕ залишається «золотим стандартом» хірургічного лікування патології надниркових залоз [1 - 5]. Оптимальним варіантом лікування одностороннього ПГА (за наявності альдостерон-продукуючої аденоми або гіперплазії надниркової залози) є ЛАЕ [6]. Дана патологія обумовлює розвиток симптоматичної артеріальної гіпертензії ендокринного генезу, яка становить 6 - 15\% спостережень загалом артеріальної гіпертензії та 15 - 20\% - резистентної артеріальної гіпертензії [7 - 9].

Мета дослідження: оцінити ефективність хірургічного лікування пацієнтів з ПГА.

\section{Матеріали і методи дослідження}

За період з 2014 по лютий 2018 р. в клініці госпітальної хірургії Запорізького державного медичного університету на базі відділення трансплантації та ендокринної хірургії Запорізької обласної клінічної лікарні обстежили та оперували 127 пацієнтів 3 патологією надниркових залоз. ПГА діагностували у 46 пацієнтів, із них 23 проведено оперативне лікування з використанням ендоскопічних методик. Жінок було 15 (65\%), чоловіків - 8 (35\%). Вік пацієнтів варіював від 34 до 72 років, середній вік становив $(52,3 \pm 9,5)$ року. Тривалість захворювання на артеріальну гіпертензію становила в середньому 8 років (від 1 міс до 35 років): менше 8 років - у 11 пацієнтів (1-ша група), більше 8 років - у 12 пацієнтів (2-га група). За віком, по- казниками САТ, ДАТ, розміром пухлини надниркової залози, концентрацією альдостерону, реніну, калію, ТЗСЛШ, ТМШП, ММЛШ, показником фракції викиду (ФВ) відмінностей між обома групами пацієнтів не виявлено (табл. 1).

За даними КТ (МРТ) правобічна локалізація аденом надниркових залоз встановлена у 10 (43,5\%) пацієнтів, лівобічна - у 7 (30,4\%), двобічна - у 6 (26,1\%), іх розмір становив $(18,3 \pm 6,7)$ мм.

ПГА діагностували відповідно до Клінічних практичних рекомендацій з діагностики та лікування первинного гіперальдостеронізму (Clinical Practical Guideline - The Management of Primary Aldosteronism; 2008, 2016). Скринінг патології складався з трьох діагностичних етапів. На першому етапі застосовували специфічні лабораторні методи: визначення концентрації альдостерону, кортизолу, адренокортикотропного гормону в плазмі крові, активності (концентраціi) реніну плазми, альдостерон-ренінового співвідношення (АРС), рівня калієміі. Другий етап полягав у застосуванні навантажувальних проб. Віддавали перевагу навантажувальній пробі з 2 л фізіологічного розчину, пробі з 50 мг каптоприлу. Для виключення субклінічної гіперкортизолемії (синдром преКушинга) на початку другого етапу проводили нічний дексаметазоновий тест. На третьому заключному етапі поєднували застосування інструментальних методик з метою візуалізації органічної патології надниркових залоз (КТ, МРТ) та визначення підтипу ПГА (селективний відбір крові з надниркових вен).

Всім пацієнтам хірургічне лікування проводили з використанням ендоскопічних методів. Лапароскопічну адреналектомію виконали 19 (82,7\%) пацієнтам, лапароскопічну резекцію надниркової залози - 4 (17,3\%). У 6 (26\%) пацієнтів операції були симультанними (2 - 3 етапи) (фенестрація кісти печінки, герніопластика пропіленовою сіткою, холецистектомія).

Методика лапароскопічної адреналектомії. Операцію виконуємо під ендотрахеальним наркозом з використанням штучної вентиляції легенів. Позиція пацієнта лате-

\begin{tabular}{|c|c|c|c|}
\hline \multicolumn{4}{|c|}{ Характеристика пацієнтів у залежності від тривалості захворювання на артеріальну гіпертензію } \\
\hline \multirow{2}{*}{ Показник } & \multicolumn{2}{|c|}{ Група пацієнтів } & \multirow{2}{*}{$\mathrm{p}$} \\
\hline & 1-ша $(n=11)$ & 2 -га $(n=12)$ & \\
\hline \multicolumn{4}{|l|}{ Стать } \\
\hline чоловіки & 1 & 7 & \\
\hline жінки & 10 & 5 & \\
\hline Вік, роки & $48,7 \pm 10,2$ & $56,2 \pm 6,7$ & 0,1 \\
\hline САТ, кПа (мм рт. ст.) & $22,1 \pm 1,9(165,4 \pm 14)$ & $23,1 \pm 3,1(174 \pm 23,96)$ & 0,29 \\
\hline ДАТ, кПа (мм рт. ст.) & $13,4 \pm 1,3(100,83 \pm 9,96)$ & $15,3 \pm 4,5(114,54 \pm 30,12)$ & 0,15 \\
\hline Розмір пухлини, мм & $17,23 \pm 7,8$ & $19,41 \pm 8,57$ & 0,63 \\
\hline \multicolumn{4}{|l|}{ Концентрація } \\
\hline альдостерону, пг/мл & $386,67 \pm 188,54$ & $383,31 \pm 211,27$ & 0,96 \\
\hline реніну, нг/л & $10,22 \pm 10,34$ & $9,17 \pm 11,86$ & 1,00 \\
\hline калію, ммоль/л & $3,9 \pm 0,25$ & $3,41 \pm 0,83$ & 1,00 \\
\hline ТзслШ, мм & $12,39 \pm 2,57$ & $11,98 \pm 1,6$ & 1,00 \\
\hline ТМШП, мм & $12,78 \pm 3,06$ & $13,16 \pm 2,85$ & 0,78 \\
\hline$\Phi B, \%$ & $67,24 \pm 8,48$ & $61,55 \pm 4,5$ & 0,10 \\
\hline ММлш, г & $277,45 \pm 108,62$ & $253,62 \pm 61,46$ & 0,55 \\
\hline
\end{tabular}




\begin{tabular}{|c|c|c|c|}
\hline \multirow{2}{*}{ Показник } & \multicolumn{2}{|c|}{ Строки визначення } & \multirow{2}{*}{$\mathrm{p}$} \\
\hline & до лікування & після лікування & \\
\hline САТ, кПа (мм рт. ст.) & $22,0 \pm 1,7(165,4 \pm 13,04)$ & $17,9 \pm 1,5(134,16 \pm 11,4)$ & 0,00003 \\
\hline ДАТ, кПа (мм рт. ст.) & $14,0(105,00)$ & $10,7(80,00)$ & 0,002 \\
\hline Альдостерон, пг/мл & $385,06 \pm 195,1$ & 58,86 & 0,0014 \\
\hline Ренін, нг/л & $9,67 \pm 8,96$ & $1,85 \pm 1,5$ & 0,64 \\
\hline APC & 10,94 & 3,99 & 0,44 \\
\hline Калій, ммоль/л & $3,59 \pm 0,39$ & $4,67 \pm 0,53$ & 0,002 \\
\hline ТМШП, мм & $11,38 \pm 1,84$ & $11,68 \pm 3,42$ & 0,74 \\
\hline ТЗСлШ, мм & $11,55 \pm 1,62$ & $12,46 \pm 2,51$ & 0,15 \\
\hline$\Phi \mathrm{B}, \%$ & 59,88 & 64,00 & 0,67 \\
\hline ММлШ, г & $243 \pm 73,99$ & $240,2 \pm 85,95$ & 0,15 \\
\hline
\end{tabular}

ральна «декубітальна» контралатеральна стороні ураження надниркової залози з нахилом поперекової області донизу під кутом $60^{\circ}$ по відношенню до операційного стола. Карбоксиперитонеум (2,0 кПа, або 15 мм рт. ст.) створюємо з використанням голки Вереша або за методикою Н. M. Hassan. Виконуючи правобічну адреналектомію використовуємо чотири троакарних доступи, лівобічну - три. Після введення лапароскопа в черевну порожнину проводимо ревізію. Наступні троакари вводимо під прямим візуальним контролем. Адреналектомію виконуємо з використанням ультразвукового скальпеля «Ultracision» («Ethicon», USA). 32012 р. правобічну адреналектомію виконуємо за запатентованою методикою, особливістю якої $€$ попередження пошкодження нижньої порожнистої вени і верхнього полюса нирки.

Результати оперативного лікування пацієнтів з ПГА оцінювали згідно зі стандартними і клініко-біохімічними критеріями PASO (Primary Aldosteronism Surgical Outcomes).

Статистично дані опрацьовували за допомогою пакетів програм «Excel», «Statistica 10.0». Відповідність виду розподілу ознаки закону нормального розподілу аналізували із застосуванням критеріїв КолмогороваСмирнова, Шапіро-Уілка. Для порівняння середніх значень вибірок, дані яких розподілені за нормальним законом, використовували параметричний t-критерій Ст'юдента. Непараметричні критерії Манна-Уітні, ВальдаВольфовіца, Колмогорова-Смирнова для непозв'язаних груп, критерії знаків, Вілкоксона для пов'язаних груп використовували, описуючи розподіл ознаки, що відрізнявся від нормального, або малі вибірки. Отримані результати у разі нормального розподілу ознак розраховували за допомогою середнього значення та стандартного відхилення ( $\pm \pm \sigma)$, ненормального - за допомогою медіани, 25-го і 75-го перцентиля (Ме 25 і 75\%). Статистично значущими вважали результати, якщо рівень статистичної значущості був менше 0,05 (p<0,05).

\section{Результати}

Середня тривалість ендоскопічних втручань становила 150 (від 120 до 200) хв, симультанних операцій - (146,6

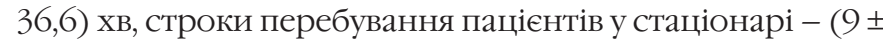
$2,1)$ дня. Конверсій, післяопераційних ускладнень, смертності вдалося уникнути. Період спостереження тривав від 6 міс до 3 років.

\begin{tabular}{|c|c|c|c|c|}
\hline Таблиця 3. & $\begin{array}{l}\text { Порівняльна } \\
\text { хірургічного }\end{array}$ & $\begin{array}{l}\text { кка ре } \\
\text { зання }\end{array}$ & $\begin{array}{l}\text { татів } \\
\text { ієнтів }\end{array}$ & \\
\hline \multirow{3}{*}{ Результат } & & \multicolumn{3}{|c|}{ Критерії оцінки } \\
\hline & & стандартні, n=23 & \multicolumn{2}{|c|}{ PASO, $n=23$} \\
\hline & aбc. & $\%$ & абс. & $\%$ \\
\hline \multicolumn{5}{|c|}{ Біохімічне одужання } \\
\hline повне & 10 & 43,5 & 21 & 91,3 \\
\hline часткове & 13 & 56,5 & 2 & 8,7 \\
\hline \multicolumn{5}{|c|}{ Клінічне одужання } \\
\hline повне & 10 & 43,5 & 9 & 39,2 \\
\hline часткове & 13 & 56,5 & 14 & 60,8 \\
\hline
\end{tabular}

Порівняльний аналіз результатів оперативного лікування показав статистично достовірне зниження показників САТ, ДАТ, концентрації альдостерону і підвищення рівня калієміі (табл. 2).

Оцінка результатів проведеного оперативного лікування пацієнтів з ПГА за стандартними критеріями та критеріями PASO представлена в табл.3.

\section{Обговорення}

Згідно з літературними джерелами у пацієнтів, яким виконали адреналектомію з приводу ПГА, надалі за даними ехокардіоскопії фіксували нормалізацію показників ММлш і діастолічного наповнення лівого шлуночка. Регрес змін міокарда є відмінною рисою лікування ПГА, на відміну від есенціальної артеріальної гіпертензії [10 - 13]. Кореляційний аналіз, проведений нами, не продемонстрував статистично достовірного зв'язку між рівнем альдостерону і ММЛШ, ТМШП, ТЗСЛШ у пацієнтів до і після оперативного лікування.

Клінічні результати хірургічного лікування пацієнтів 3 ПГА, оцінені за критеріями PASO і за стандартними критеріями, майже однакові: повне одужання - 39,2 і 43,5\%, часткове - 60,8 і 56,5\% відповідно. Біохімічні результати, оцінені аналогічно, мали суттеву різницю: повне одужання - 91,3 і 43,5\%, часткове - 8,7 і 56,5\% відповідно. Отримані дані порівнянні з результатами багатоцентрових досліджень з застосуванням критеріїв PASO для оцінки результатів лікування 705 пацієнтів: повного біохімічного одужання досягнуто в 94\% (83 - 100\%) спостережень, клінічного - в 37\% (17 - 62\%) спостережень [14, 15]. Ми оцінили сумарні (біохімічні і клінічні) результати хірургічного 
лікування за критеріями PASO і стандартними критеріями: повне одужання констатували в 65,25 і 43,5\% спостережень, часткове - в 34,8 і 56,5\% відповідно.

\section{Висновки}

1. У хірургічному лікуванні пацієнтів з аденомами надниркових залоз, що супроводжуються ПГА, слід надавати перевагу лапароскопічним методам (адреналектомії, резекціi).

2. Використання мініінвазивних методів хірургічного лікування пацієнтів з ПГА має статистично достовірну ефективність.

3. Перевагою використання клініко-біохімічних критеріїв PASO для оцінки результатів хірургічного лікування пацієнтів з ПГА порівняно із стандартними критеріями оцінки є їх комплексність.

4. Після хірургічного лікування ПГА повне біохімічне одужання настає у 91,3\% пацієнтів, повне клінічне - у $39,2 \%$, часткове біохімічне - у 8,7\%, часткове клінічне - у 60,8\% пацієнтів.

\section{References}

1. Sotelo R, Arriaga J, Aron M editors. Complications in Robotic Urologic Surgery. Springer; 2018. 135-9. doi: 10.1007/978-3-319-62277-4.

2. Rybakov SI. History of surgery of adrenal cortex tumors (part 1). Klinichna endokrynolohia ta endocrynna khirurhiia, 2013;3(44):5560. doi:10.24026/1818-1384. [In Ukrainian].

3. Chen SF, Chueh SC, Wang SM, Wu VC, Pu YS, Wu KD, Huang KH. Clinical outcomes in patients undergoing laparoscopic adrenalectomy for unilateral aldosterone producing adenoma: partial versus total adrenalectomy. J Endourol. 2014 Sep; 28(9):1103-6. doi: 10.1089/end.2014.0102.

4. Van Uitert A, d' Ancona FCH, Deinum J, Timmers HJLM, Langenhuijsen JF. Evaluating the learning curve for retroperitoneoscopic adrenalectomy in a high-volume center for laparoscopic adrenal surgery. Surg Endosc. 2017 Jul;31(7):2771-5. doi: 10.1007/s00464-016-5284-0.

5. Taskin HE, Berber E. Robotic adrenalectomy. Cancer J. 2013 MarApr;19(2):162-6. doi: 10.1097/PPO.0b013e31828ba0c7.

6. Funder JW, Carey RM, Mantero F, Murad MH, Reincke M, Shibata H, Stowasser M, Young WF Jr. The Management of Primary Aldosteronism: Case Detection, Diagnosis, and Treatment: An Endocrine Society Clinical Practice Guideline. J Clin Endocrinol Metab. 2016 May;101(5):1889916. doi: 10.1210/jc.2015-4061.
7. Shchkaturova LV. Essential issues of diagnostic of primary hyperaldosteronism. Klinichna endocrynolohia ta endokrynna khirurhia, 2015; 2(50):77-80. doi: 10.24026/1818-1384.2(50).2015.74990. [in Ukrainian].

8. Williams TA, Lenders JWM, Mulatero P, Burrello J, Rottenkolber M, Adolf C, et al. Primary Aldosteronism Surgery Outcome (PASO) investigators. Outcomes after adrenalectomy for unilateral primary aldosteronism: an international consensus on outcome measures and analysis of remission rates in an international cohort. Lancet Diabetes Endocrinol. 2017 Sep;5(9):689-99. doi: 10.1016/S2213-8587(17)30135-3.

9. Monticone S, Burrello J, Tizzani D, Bertello C, Viola A, Buffolo F, et al. Prevalence and clinical manifestations of primary aldosteronism encountered in primary care practice. J Am Coll Cardiol. 2017 Apr 11;69(14):1811-20. doi: 10.1016/j.jacc.2017.01.052.

10. Prejbisz A, Warchoł-Celińska E, Lenders JW, Januszewicz A. Cardiovascular risk in primary hyperaldosteronism. Horm Metab Res. 2015 Dec;47(13):973-80. doi: 10.1055/s-0035-1565124.

11. Rossi GP, Cesari M, Cuspidi C, Maiolino G, Cicala MV, Bisogni V, et al Long-term control of arterial hypertension and regression of left ventricular hypertrophy with treatment of primary aldosteronism. Hypertension. 2013 Jul;62(1):62-9. doi: 10.1161/HYPERTENSIONAHA.113.01316.

12. Marzano L, Colussi G, Sechi LA, Catena C. Adrenalectomy is comparable with medical treatment for reduction of left ventricular mass in primary aldosteronism: meta-analysis of long-term studies. Am J Hypertens. 2015 Mar;28(3):312-8. doi: 10.1093/ajh/hpu154.

13. Zennaro MC, Boulkroun S, Fernandes-Rosa F. An update on novel mechanisms of primary aldosteronism. J Endocrinol.2015 Feb;224(2):R63-77. doi: 10.1530/JOE-14-0597.

14. Miller BS, Turcu AF, Nanba AT, Hughes DT, Cohen MS, Gauger PG, Auchus RJ. Refining the definitions of biochemical and clinical cure for primary aldosteronism using the primary aldosteronism surgical outcome (PASO) classification system. World J Surg. 2018 Feb;42(2):453-63. doi: 10.1007/s00268-017-4311-1.

15. Williams TA, Lenders WM, Mulatero P, et al. Outcome of adrenalectomy for unilateral primary aldosteronism: international consensus and remission. Lancet Diabetes Endocrinol. 2017 Sep;5(9):689-99. doi: 10.1016/S2213-8587(17)30135-3. 